\title{
Article
}

\section{Draft Animals, Farm Machines and Sustainable Agricultural Production: Insight from China}

\author{
Xiaoshi Zhou ${ }^{1}$ (D), Wanglin $\mathrm{Ma}^{2}{ }^{\mathbb{D}}$ and Gucheng $\mathrm{Li}^{1 \text {,* }}$ \\ 1 College of Economics \& Management, Huazhong Agricultural University, Wuhan 430070, China; \\ Xiaoshi.Zhou@outlook.com \\ 2 Department of Global Value Chains and Trade, Faculty of Agribusiness and Commerce, Lincoln University, \\ Lincoln 7647, Christchurch, New Zealand; Wanglin.Ma@lincoln.ac.nz \\ * Correspondence: lgcabc@mail.hzau.edu.cn; Tel.: +86-027-87286896
}

Received: 19 July 2018; Accepted: 22 August 2018; Published: 24 August 2018

\begin{abstract}
Although draft animals have been playing an essential role in agricultural production worldwide, in recent decades there has been a trend towards replacing draft animals with farm machines. In the areas facing labour shortage due to rural-to-urban migration, the use of farm machines is especially expected to enhance agricultural production and productivity. However, little is known about the extent to which the farm machine use substitutes draft animal use and how the two production activities jointly affect agricultural performance. To fill this gap, this paper attempts to examine the long-run and short-run effects of farm machine use on draft animal use using a pooled mean group estimator, and to estimate the joint effects of farm machine use and draft animal use on agricultural productivity using a panel production function model. The empirical results show that a $1 \%$ increase in farm machine use rate tends to decrease draft animal use by $2.82 \%$ in the long-run, but it does not have a statistically significant impact on draft animal use in the short-run. In addition, we find that output elasticity of farm machine use has increased from -0.161 in 1978 to 0.170 in 2012, while that of draft animal use has decreased from 0.185 to -0.129 over the same time period. Our findings highlight the importance of government's efforts in promoting an agricultural transition from animal power to machine power in order to increase sustainable agricultural production.
\end{abstract}

Keywords: draft animals; farm machines; agricultural productivity; pooled mean group (PMG); panel production function

\section{Introduction}

Traditionally, draft animals have played an essential role in agricultural production in many developing and transition countries. Kienzle et al. [1] estimated that around 55\% of the smallholder farmers in Swaziland still rely on draft animal power for land cultivation, and more than $88 \%$ of draft animals found on the Swazi National Land are cattle. Animal power is generally affordable and accessible to the smallholder farmers. The availability of animal power enables rural laborers to increase production efficiency and productivity. Available evidence has revealed that relative to maize farmers who used hand hoes in Kenya, those who used draft animal power obtained higher yields and operated at a higher economic efficiency [2].

However, with the emergence and development of farm machines, the role of draft animals in agricultural production has been gradually replaced by farm machines. A number of possible reasons for this trend have been identified. Mrema et al. [3] summarized five reasons that explain the shift from animal power to machine power in agricultural production, including (a) expansion of the area under cultivation; (b) facilitation of timely farm operations to increase productivity; (c) the 
multi-functional use of mechanization; (d) overcoming seasonal labor shortages; and (e) reduction of the drudgery associated with the use of human muscle power for tasks such as hand hoeing for primary tillage. Some empirical studies have demonstrated that farm machines can not only help address labour shortage issues (due to, primarily rural-to-urban migration for seeking higher salary opportunities) facing farm households, but also save farmers' time used for farm activities and allow them to reallocate additional time to off-farm activities [1,4-7]. Ahmed and Goodwin [4] showed that adoption of labour-saving technologies such as tractors and power tillers increases the probability of participation in the rural off-farm sector in Bangladesh. A study on China by Wang et al. [5] also found that there exists a substitution effect between rural labour and machines through estimating frontier production function.

In addition to the substituive effects of farm machines on rural labour usage and re-allocation, farm machine use appears to have a positive impact on agricultural production. Several studies have shown that farm machine use increases agricultural productivity [8-12]. Rahman et al. [11] revealed that the yield of wheat under mechanization ( $2.65 \mathrm{ton} / \mathrm{ha}$ ) is higher than that of traditional farms (2.57 ton/ha) in northern Bangladesh. Ma et al. [9] found that farm machine use has a positive and statistically significant impact on maize yields in China. In their analysis on Ghana, Benin [12] showed a positive relationship between the use of mechanization services by farming households and farm yields. Farm machine use can not only facilitate the intensification of agricultural production through quicker turnaround time, timely use of water, better plant protection, and more efficient harvesting, but also reduce drudgery. In their investigation of sub-Saharan African smallholders, Sims et al. [7] also showed that the use of farm machines enables smallholders to increase farm yields through the adoption of intensification, conservation agriculture, and other climate-resilient, labourand energy-efficient, and gender-friendly practices.

Although the use of farm machines has become increasingly important and dominant for effective and efficient farm operations, farm machine use may have different impacts on draft animal use in different production stages such as ploughing, sowing and harvesting due to differences in terms of farm machine availability, production conditions, and requirements of power intensity $[9,13]$. Understanding the substitutive effects of farm machine use in different production stages on draft animal use would provide important implications for public policy efforts to promote farm machine use and enhance sustainable agricultural production in the long-run. However, there is currently a lack of knowledge about the extent to which the farm machine use substitutes draft animal use. Moreover, most of the studies mentioned previously have either analysed the association between draft animal use and agricultural production $[2,14]$, or the impact of farm machine use on agricultural productivity $[5,9,12,15]$. The estimates may be biased if households are jointly making decisions to use draft animals and to use farm machines in their efforts to enhance agricultural production. However, very few have considered the joint effects of draft animal use and farm machine use on agricultural productivity.

The primary objective of this study is, therefore, to analyse the interactive relationship between draft animal use, farm machine use, and agricultural productivity, using data collected by the National Bureau of Statistics of China from 28 provinces of China for the period 1978-2012. We attempt to contribute to the literature in two ways. First, we provide a first attempt to analyse the impact of farm machine use on draft animal use, with a particular focus on different production stages including ploughing, sowing and harvesting. In doing so, we shed light on the long-run and short-run relationship between farm machine use and draft animal use by employing a pooled mean group (PMG) estimator. Previous studies have only focused on the qualitative analysis or evaluated the average effect of farm machine use on draft animal use [16], but have not distinguished the short-run and long-run relationship between farm machine use and draft animal use. For the purpose of comparisons, we also present the results estimated from fixed effects (FE) and first difference approaches. Second, we analyse the joint effects of draft animal use and farm machine use on agricultural productivity, by using a panel production function model with fixed effects. 
The rest of the paper is structured as follows. Section 2 presents the background information regarding the agricultural production transition from draft animal use to farm machine use. Section 3 presents the data and descriptive statistics. The empirical models are presented in Section 4, and the empirical results are discussed in Section 5. Section 6 concludes with policy implications.

\section{The Agricultural Production Transition from Draft Animal Use to Farm Machine Use}

In many developing countries, draft animals have been identified a significant tool in providing farmers with farm power to facilitate agricultural production. Draft animals are usually considered the most critical and costly piece of capital in pre-mechanized agriculture [17]. In some hilly and mountainous regions where farm machinery services and the development of farm machines that match the local production conditions have lagged, agricultural production relies heavily on draft animal power. Moreover, the draft animal also provides a possibility for farmers to use farmyard manure or compost to replenish or maintain soil nutrients. A study on China showed that the production elasticity of farm manure is 0.17 on average, highlighting the importance of farmyard manure in enhancing agricultural productivity [18].

Despite the significant role draft animals play in agricultural production, the development of advanced technologies such as farm machines gradually shows a more critical role in agricultural production areas facing labour shortages due to rural-to-urban migration $[5,9,19,20]$. Farm machines can facilitate increased output of higher value products while eliminating the drudgery associated with human and/or animal muscle-powered agricultural production. In rural regions, men usually migrate in search of higher incomes while women are left in charge of household farm production. It is reported that women contribute to $60-80 \%$ of the labour for food production in sub-Saharan Africa, while farm machines can provide women in rural areas with opportunities to adapt to cultural, social and traditional work norms, and to the overall development of local economies [7]. In China, the real wage of labour has been rapidly growing with a double-digit annual increase since 2003, which induces the substitution of farm labour and animal power by machinery power [21]. In the past two decades, China has witnessed an increase in agricultural mechanisation and a decrease in draft animal use. Due to the introduction of subsidy for purchasing agricultural machinery and the release of the Agricultural Mechanization Promotion Law of the People's Republic of China in 2004, the mechanisation level of agricultural production increased by 19\% from 2005 to 2012 in China, while the number of draft animals decreased by $57 \%$ during the same time period. Nevertheless, animal power use is still inevitable in China due to hilly and mountainous characteristics of farmland in some regions. It is estimated that more than 30 million head of draft animals were being used in agricultural production in China by the end of 2012.

\section{Data and Descriptive Statistics}

\subsection{Data Source}

The data used in the present study are mainly from China's Rural Statistics Yearbooks (1978-2013), China Yearbook of Rural Household Survey (1980-2013) and China's Education Statistical Yearbook (1988-2013), which are all collected by National Bureau of Statistics of China. In the present study, we focus on our analyses using the panel data of 28 provinces (Anhui, Beijing, Shanghai, Tianjin, Yunnan, Inner Mongolia, Sichuan, Ningxia, Shandong, Shanxi, Guangdong, Guangxi, Xinjiang, Jiangsu, Jiangxi, Hebei, Henan, Zhejiang, Hubei, Hunan, Gansu, Fujian, Guizhou, Shaanxi, Qinghai, Liaoning, Jilin and Heilongjiang) for the period of 1978-2012 due primarily to two reasons. First, the data on draft animal use were not collected after 2012 by the National Bureau of Statistics of China, but our primary objective in this study is to investigate the interactive relationship between draft animal use, farm machine use, and agricultural productivity. Second, we focus only on the analysis of 28 provinces, because the other parts of China (e.g., Tibet, Chongqing and Hainan province) had data missing and administrative division issues during the period of 1978-2012. 
The variables used in the present study are mainly selected from the National Bureau of Statistics of China. In particular, the draft animal use variable refers to the total number of animals recorded at the end of each survey year. The information on draft animals including horses, donkeys, farm cattle, buffaloes, calves and camels are purposively collected by National Bureau of Statistics of China during the surveys, because those animals can provide power for farm operations such as ploughing, transportation, and milling. Farm machine use is a variable that is measured by the accumulated farm machine use rate in three crucial production stages including ploughing, sowing and harvesting. Although some previous studies have used total machine power in their efforts to analyse the impact of farm machine use on farm performance [22,23], it is worth mentioning here that the total machine power does not capture the information of farm machines used through purchased services, which can only capture the partial effects of farm machine use. As highlighted by Ji et al. [6] and Wang et al. [5], purchasing machinery and/or buying machinery services are two primary means for smallholder farmers to get access to farm machines during agricultural production in China. Thus, it is more reasonable to employ farm machine use rate rather than total machine power. Agricultural productivity refers to the gross value obtained from agricultural production, which is measured at a per hectare base. The variables including labour, fertilizer, transportation, off-farm income, education, ploughing, sowing and harvesting are also selected in consideration of data availability and included in the analysis.

\subsection{Descriptive Statistics}

The definition and descriptive statistics of the variables are presented in Table 1. It can be observed from Table 1 that every province used about 0.45 head of draft animals per hectare of land. The farm machine use rate on cultivated land is $27.2 \%$ on average. The agricultural productivity is 4623 Yuan/hectare on average. The average number of labourers engaged in agricultural production is about 2 persons per hectare, and the fertiliser used for agricultural production is around $225 \mathrm{~kg} / \mathrm{hectare}$. The average rural residents have 6.87 years of schooling. With respect to the mechanisation rate in different production stages, the results presented in Table 1 show that the mean use rate of farm machines for ploughing in agricultural production is $40.1 \%$, whereas the mean use rates for sowing and harvesting are $23.4 \%$ and $14.4 \%$, respectively.

Table 1. Definition and descriptive statistics of variables.

\begin{tabular}{cccc}
\hline Variables & Definition & Mean & S.D. \\
\hline Draft animal use & Draft animal use per hectare (head) & 0.448 & 0.312 \\
Farm machine use & The farm machine use rate & 0.272 & 0.202 \\
Agricultural productivity & Gross agricultural production value per hectare (Yuan) ${ }^{\text {a }}$ & 4622.578 & 4815.123 \\
Labour & Labour input per hectare (person) & 1.987 & 0.724 \\
Fertiliser & Fertiliser input (kg/hectare) & 224.553 & 121.782 \\
Transportation & The road length per square kilometre (km/ $/ \mathrm{km}^{2}$ ) & 0.360 & 0.337 \\
Off-farm income & The proportion of off-farm income to rural households' & 0.323 & 0.175 \\
Education & total income per capita & 6.868 & 1.503 \\
Ploughing & The average schooling year of rural people (year) & 0.401 & 0.243 \\
Sowing & The rate of land ploughed by machines & 0.234 & 0.254 \\
Harvesting & The rate of land sowed by machines & 0.144 & 0.245 \\
\hline
\end{tabular}

a Yuan is the Chinese currency, with 1 USD = 6.78 Yuan in 2018; the original value of agricultural productivity was deflated to a base year of 1978 using the agricultural gross values index released by the National Bureau of Statistics of China.

Figure 1 demonstrates the negative relationship between draft animal use and farm machine use rate from 1978 to 2012 at the national level. The information illustrated in Figure 1 shows that the number of draft animal used was increasing before 1996, then experienced a sharp decrease. The reason for the sharp decline in draft animal use between 1996 and 1997 is potential because the National Bureau of Statistics of China made official adjustment to the data based on the second agricultural census results in 1997. In particular, the number of draft animals used per hectare of 
land has decreased from 0.58 head in 1996 to 0.19 head in 2012. In comparison, farm machine use was dramatically increasing over time. The use rate of farm machines in 1978 was $15.91 \%$ and then increased to $51.80 \%$ in 2012 , an increase of approximately $225.58 \%$. The dramatic increase of farm machine use is not surprising, because over time more and more rural households become aware of the benefits associated with farm machines, and also because farm machines and machinery services have become gradually available on the markets in rural regions. In their survey for 453 rural households in Anhui province of China, Ji et al. [6] showed that more than half of the surveyed households $(54.5 \%)$ possessed certain kinds of farm machines such as small tractors for towing and ploughing, seeders and/or transport equipment.

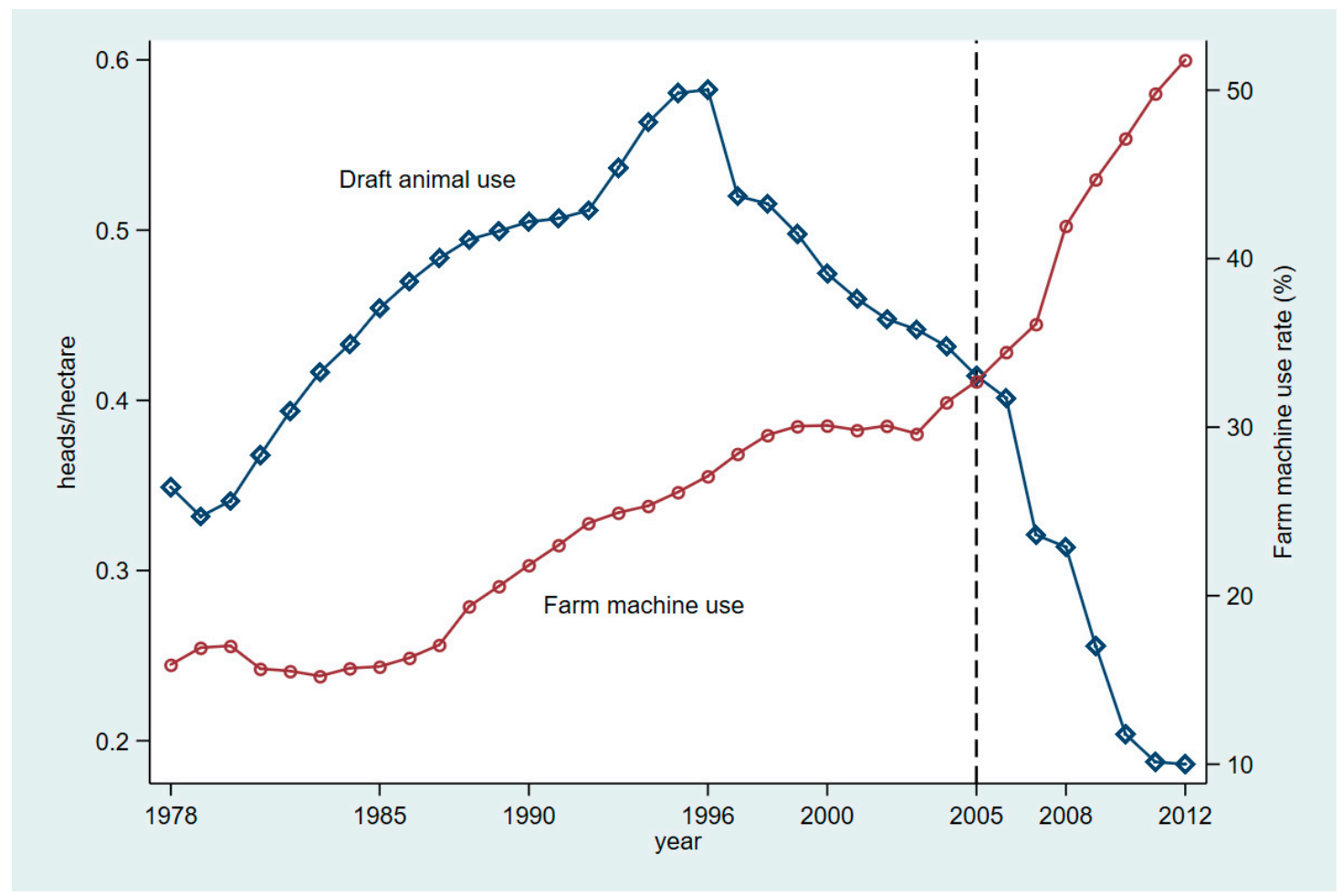

Figure 1. The changes of draft animal use and farm machine use rate from 1978 to 2012.

To facilitate our understanding regarding the relationship between draft animal use and farm machine use, we plotted the changes in draft animals and farm machine use rate at provincial levels and presented the results in Figure 2. The Figure 2 shows that there is a noticeable decrease in terms of draft animal use, and a dramatic increase in farm machine use rate at provincial levels, which is largely consistent with the observation in Figure 1. To explore whether the significant changes of farm machine use and draft animal use is due to the changes of farm size, we plotted the changes of the growth rate of land from 1978 to 2012 and presented the results in Figure A1 in Appendix A. This shows that the rate of land used for crop cultivation has no big fluctuation, suggesting that land size change is not a main factor contributing to the changes of draft animal use and farm machine use over time.

In addition, Figure 2 also shows that the magnitudes of the substitutive relationship between draft animal use and farm machine use vary across different provinces. This is not surprising, because there exist obvious differences in terms of institutional environments, social-economic conditions, and geographical characteristics among those provinces. For example, Heilongjiang, Jilin and Liaoning are located the plain regions endowed with favorable production conditions, the mechanization level of agricultural production is relatively higher than other provinces. In comparison, Guizhou and 
Yunan are located in mountainous and hilly areas, in which it is difficult to apply farm machines in agricultural production practices.

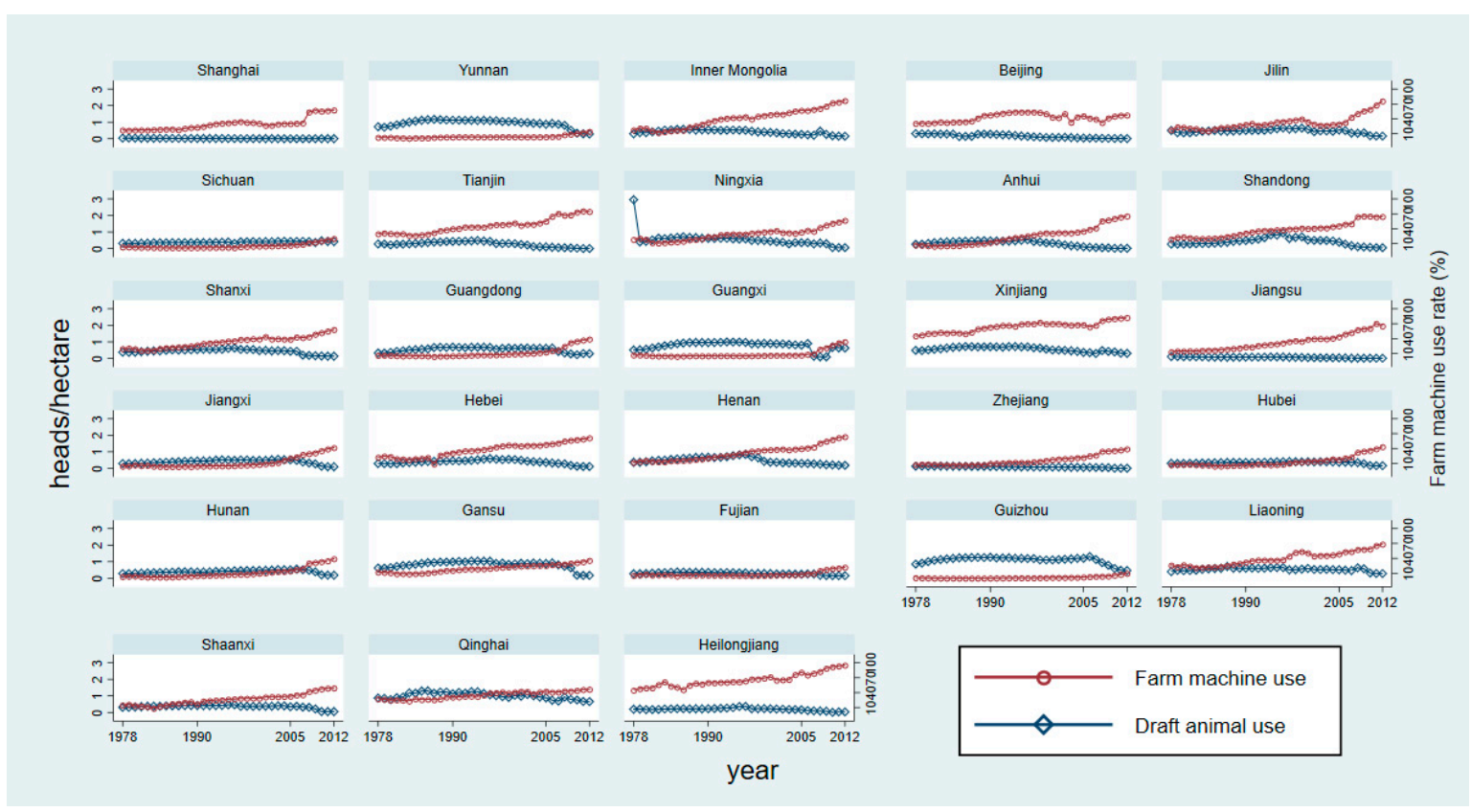

Figure 2. The changes of draft animal use and farm machine use rate at the provincial levels from 1978 to 2012.

Overall, the results presented in Figures 1 and 2 tend to suggest that farm machine use plays an increasing role in agricultural production, but the role of draft animal use is diminishing. However, the questions as to what extent that farm machine use affects draft animal use in rural China and how draft animal use and farm machine use jointly determine agricultural productivity have not been answered. The present study attempts to find answers to these questions.

\section{Empirical Models}

\subsection{Pooled Mean Group (PMG) Model}

The first objective of this study is to analyze the impact of farm machine use on draft animal use, using a PMG model. Compared with other methods such as the fixed effects model and first difference model, which only capture the static long-run effects of farm machine use on draft animal use, the pooled mean group model has the ability to explore both long-run and short-run effects of farm machine use. To begin with, we express the autoregressive distributive lag (ARDL) dynamic panel specification for separating the long-run and short-run effects as follows:

$$
\Delta D A_{i, t}=\alpha_{0}+\sum_{j=1}^{p} \lambda_{i, j} D A_{i, t-j}+\sum_{j=0}^{q} \beta_{i, j} M E_{i, t-j}+\sum_{j=0}^{q} \gamma_{i, j} X_{i, t-j}+\mu_{i}+\varepsilon_{i, t}
$$

where $D A_{i, t}$ is the number of draft animals used per hectare, with $i$ referring to the number of provinces included in the analysis and $t$ referring to the year; $\Delta D A_{i, t}$ is the first order difference of $D A_{i, t} ; D A_{i, t-j}$ refers to the lag term of draft animal use with $j$-th order lag; $M E_{i, t-j}$ is the farm machine use rate with $j$-th order lag; $X_{i, t-j}$ is a $j$-th order lag vector of control variables that include labour use, fertiliser use, transportation, off-farm income, and education; $\mu_{i}$ is the time-invariant fixed-effects for the province $i$; $\alpha_{0}$ is a constant term; $\lambda_{i, j}, \beta_{i, j}$ and $\gamma_{i, j}$ are parameters to be estimated; $\varepsilon_{i, t}$ is the idiosyncratic, time- and 
state-varying error term. After including a one lag order term for draft animal use variable to both sides of Equation (1), Equation (1) can be re-parameterized into an error-correction model as follows:

$$
\begin{gathered}
\Delta D A_{i, t}=\varphi_{i}\left(D A_{i, t-1}-\theta_{i} M E_{i, t-1}-\tau_{i} X_{i, t}\right)+\sum_{j=1}^{p-1} \lambda_{i, j}^{*} \Delta D A_{i, t-j}+\sum_{j=1}^{q-1} \beta_{i, j}^{*} \Delta M E_{i, t-j}+ \\
\sum_{j=1}^{p-1} \gamma_{i j}^{*} \Delta X_{i, t-j}+\mu_{i}+\varepsilon_{i, t}
\end{gathered}
$$

where the coefficient $\varphi_{i}$ is the error-correcting speed of adjustment term, which reveals how strongly the dependent variable reacts to the deviation from the long-term level. If $\varphi_{i}=0$, this would suggest that farm machine use and other control variables have no long-run effects on draft animal use. The PMG estimator allows us to estimate the homogenous effects of farm machine use on draft animal use in the long-run, and to estimate the heterogeneous effects across different provinces in the short-run [24,25]. In particular, the parameter vectors, $\theta_{i}$ and $\tau_{i}$, capture the long-run effects of farm machine use and other control variables on draft animal use, respectively. The short-run effects of farm machine use and other control variables on draft animal use are captured by the parameters $\beta_{i, j}^{*}$ and $\gamma_{i, j}^{*}$, respectively. The PMG approach has been applied in previous studies. For example, using the PMG approach, Kangasniemi et al. [26] analysed the relationship between migration and productivity for Spain and the UK, and Bachewe and Headey [27] investigated how food price affects wage increase in Ethiopia.

The direct estimation of Equation (2) would be problematic if the draft animal use and farm machine use are non-stationary. For a stationary $\varepsilon_{i, t}$, it must be the case that the variables are integrated in one order, denoted by $I(1)$. We formally test the non-stationarity of draft animal use, farm machine use and other covariate variables, using the unit root (IPS) test proposed by Im, Pesaran and Shin [28]. The IPS test is a very popular first-generation panel unit root test, which has been used to test whether the variables used for empirical analysis are non-stationary and possess a unit root. The IPS test does not account for cross-sectional dependence, but allows for heterogeneity across panels. The null hypothesis of the IPS test is that all panels contain a unit root. Rejection of the null hypothesis would suggest that a non-zero fraction of the panels represents stationary processes.

To evaluate if the variables are cointegrated, we employ both the Westerlund test and the Pedroni test $[29,30]$. The Westerlund test is designed to test whether the error correction in a conditional error correction model is equal to zero, while in the Pedroni test the estimated slope coefficients are permitted to vary across individual members of the panel. The null hypothesis of the two tests is the same, and both of them assume that there is no cointegration. Failing to accept the null hypothesis would suggest that draft animal use, farm machine use and other covariate variables are cointegrated in all panels with a panel-specific cointegrating vector.

Another issue that needs to be accounted for is the potential endogeneity issue associated with farm machine use, given the fact that farmers decide themselves on whether or not to use machines on their farms [9]. Usually, the endogeneity issue can be addressed by using instrumental approaches such as the two-stage least squares (2SLS) regression model. However, the endogeneity issues of explanatory variables can be safely ignored in the present study, because the ARDL model can produce consistent estimates as long as the lag order is appropriately selected [24]. The appropriate lag order can be selected based on the Akaike information criterion (AIC) and the Bayesian information criterion (BIC). After the pre-tests, we find that the first lag order is the most suitable lag length, which is thus used in the present study. For the purposes of comparison, we also presented the results estimated from the fixed effects and first difference models.

\subsection{Production Function Model with Fixed Effects}

The second objective of this study is to analyse the joint effects of farm machine use and draft animal use on agricultural productivity, using a production function model with fixed effects. To begin with, we consider that a production process uses $n$ inputs to produce one output and express the production function as follows:

$$
Y_{i t}=f\left(x_{1, i t}, \cdots, \cdots x_{n, i t}, T\right)
$$


where $Y_{i t}$ refers to agricultural productivity per hectare of land for province $i$ in year $t$, which is measured by the gross value per hectare obtained from agricultural production. $x_{n, i t}$ is the $n$-th input used in the province $i$ in year $t . T$ is used to capture the technological progress (a linear time trend).

In empirical studies, both the Cobb-Douglas form and translog functional form have been used to estimate the output elasticity of inputs [31,32]. In particular, the Cobb-Douglas form is mainly used to measure and compute constant production elasticity, while the translog functional form is used to represent the production function and track time-varying elasticity changes. To identify an appropriate functional form for this study, both the Cobb-Douglas form and the translog functional form are estimated in our preliminary tests. The results for a likelihood ratio test, AIC and BIC, which are presented at the bottom of Table 3, show that the Cobb-Douglas form is not nested in the translog functional form, suggesting the validity of using the translog functional form in the present study. Therefore, the translog functional form is used to estimate the production function (3), which is specified as follows:

$$
\begin{gathered}
\ln \left(Y_{i t}\right)=a_{0}+a_{i}+\alpha_{T} t+\sum_{j}^{n} \beta_{j} \ln \left(x_{j, i t}\right)+\frac{1}{2} \sum_{j}^{n} \sum_{k}^{n} \beta_{j, k} \ln \left(x_{j, i t}\right) \times \ln \left(x_{k, i t}\right)+ \\
\sum_{j}^{n} \beta_{T_{j}} \ln \left(x_{i t}\right) \times t+\beta_{T} t^{2}+v_{i t}
\end{gathered}
$$

where $\ln \left(Y_{i t}\right)$ represents the log-transformed agricultural productivity, with $i$ refering to the number of provinces and $t$ referring to the year; $\ln \left(x_{j, i t}\right)$ or $\ln \left(x_{k, i t}\right)$ refers to the log-transformed inputs including labour, draft animal use, farm machine use and fertiliser; $i$ or $j$ is the $i$ - or $j$-th number of input; $t$ is a time trend variable used to capture technological progress $(1978=1 \ldots \ldots, 2012=35) ; a_{i}$ refers to the fixed effects varying among provinces; $\alpha_{0}, \alpha_{T}, \alpha_{j}, \beta_{j, k}, \beta_{T_{j}}$ and $\beta_{T}$ are parameters to be estimated.

Taking the first derivative of Equation (4) with respect to a specific input $j$, the output elasticity of this input $j$ can be calculated as follows:

$$
E_{x_{j}}=\frac{\partial \ln \left(Y_{i t}\right)}{\partial \ln \left(x_{j, i t}\right)}=\alpha_{j}+\sum_{k}^{n} \frac{1}{2} \beta_{j k} \times \ln \left(x_{k, i t}\right)+\beta_{T_{j}} \times t
$$

where $E_{x_{j}}$ represents the output elasticity of input $x_{j}$.

\section{Empirical Results and Discussions}

\subsection{Results for Unit Root (IPS) Test and Cointergration Tests}

Table A1 in Appendix A presents the results estimated from the IPS test. The results show that the statistical values with and without inclusion of the time trend variable are statistically significant at $1 \%$ level, suggesting that the null hypothesis of non-stationarity can be rejected and all the variables used in our empirical models are integrated in the order of one I(1). Table A2 in Appendix A presents the results of the cointeragretion tests for the draft animal use equation and production function equation, relying mainly on the Westerlund test and Pedroni test. All the tested statistics including the variance ratio, modified Philips-Perron test, Philips-Perron test, and Augmented Dickey-Fuller test are statistically significant, suggesting that the null hypothesis of no cointegration can be rejected. Overall, the results presented in Tables A1 and A2 confirm the validity and appropriateness of using a pooled mean group model and panel production function model to conduct the empirical analyses in the present study.

\subsection{Impact of Farm Machine Use on Draft Animal Use}

The results for the long-run and short-run effects of farm machine use on draft animal use, which are estimated using the PMG model, are presented in Table 2. In particular, Model (1) presents the results of the impact of aggregated farm machine use on draft animal use. For a better understanding, we also estimated the impact of farm machine use in different production stages including ploughing, sowing and harvesting on draft animal use in Model (2), Model (3) and Model (4), respectively. 
Our estimates show that the long-run coefficient of the farm machine use variable is negative and statistically significant, suggesting that farm machine use does have a statistically significant and negative impact on draft animal use. The findings suggest that in the long-run, a $1 \%$ increase in farm machine use rate tends to decrease draft animal use by $2.82 \%$. However, the short-run coefficient of the farm machine use variable suggests that farm machine use does not affect draft animal use significantly in the short-run. The results, which are presented in columns 3-5 of Table 2, show that farm machine use rate at different production stages including ploughing, sowing and harvesting affects draft animal use differently, suggesting the presence of heterogeneous effects of farm machine use in agricultural production. In particular, the long-run coefficients of variables representing ploughing, sowing and harvesting suggest that a $1 \%$ increase in farm machine use rate in ploughing, sowing and harvesting tends to significantly decrease draft animal use by $1.19 \%, 1.26 \%$ and $2.88 \%$, respectively. However, in the short-run, farm machine use in ploughing, sowing and harvesting has no statistically significant impact on draft animal use.

Table 2. The impact of farm machine use on draft animal use: pooled mean group estimation.

\begin{tabular}{|c|c|c|c|c|}
\hline Variables & Model (1) & Model (2) & Model (3) & Model (4) \\
\hline Adjustment coefficients & $-0.184(-4.19) * * *$ & $-0.170(-4.27)^{* * *}$ & $-0.170(-3.98) * * *$ & $-0.224(-4.87) * * *$ \\
\hline \multicolumn{5}{|l|}{ Long-run coefficients } \\
\hline Farm machine use & $-2.818(-4.88) * * *$ & & & \\
\hline Ploughing & & $-1.194(-2.27)^{* *}$ & & \\
\hline Sowing & & & $-1.256(-2.83)^{* * *}$ & \\
\hline Harvesting & & & & $-2.876(-6.95)$ *** \\
\hline Labour & $0.215(0.93)$ & $0.377(1.43)$ & $0.050(0.18)$ & $0.409(2.04) * *$ \\
\hline Fertiliser & 0.165 (1.17) & $0.061(0.44)$ & $0.115(0.80)$ & $0.086(0.71)$ \\
\hline Transportation & $-5.136(-8.92)^{* * *}$ & $-5.907(-8.94) * * *$ & $-7.162(-9.23) * * *$ & $-2.991(-7.56)^{* * *}$ \\
\hline Off-farm income & $-0.362(-1.54)$ & $-0.291(-1.08)$ & $-0.576(-2.39)^{* *}$ & $-0.451(-2.00) * *$ \\
\hline Education & $0.083(1.67) *$ & $0.018(0.31)$ & $0.026(0.45)$ & $-0.004(-0.08)$ \\
\hline \multicolumn{5}{|l|}{ Short-run coefficients } \\
\hline Farm machine use & $0.587(1.34)$ & & & \\
\hline Ploughing & & $0.284(1.53)$ & & \\
\hline Sowing & & & 3.717 (1.07) & \\
\hline Harvesting & & & & $-0.079(-0.07)$ \\
\hline Labour & $0.191(1.40)$ & $0.105(0.70)$ & $0.119(0.78)$ & $0.130(0.93)$ \\
\hline Fertiliser & $0.123(3.05) * * *$ & $0.104(2.03)^{* *}$ & $0.135(2.71)^{* * *}$ & $0.158(3.25)^{* * *}$ \\
\hline Transportation & $0.539(2.24) * *$ & $0.590(2.14) * *$ & $0.942(2.66)^{* * *}$ & $0.432(1.88) *$ \\
\hline Off-farm income & $0.014(0.31)$ & $-0.005(-0.07)$ & $0.063(1.06)$ & $0.067(1.16)$ \\
\hline Education & $-0.071(-1.81) *$ & $-0.040(-0.90)$ & $-0.052(-1.34)$ & $0.047(1.09)$ \\
\hline Constant & $-0.085(-3.34)^{* * *}$ & $0.094(4.19) * * *$ & $0.145(4.91)^{* * *}$ & $0.014(0.63)$ \\
\hline Log Likelihood & 655.712 & 651.438 & 667.195 & 663.056 \\
\hline Observation & 952 & 952 & 952 & 952 \\
\hline
\end{tabular}

Note: $t$ statistics in parentheses; ${ }^{*} p<0.1,{ }^{* *} p<0.05,{ }^{* * *} p<0.01$.

With respect to other factors that also affect draft animal use, the long-run coefficient of the transportation variable is negative and statistically significant, suggesting that convenient transportation appears to reduce the number of draft animals used. Access to better rural infrastructure enables farmers to migrate easily to seek better salaries and rely less on agricultural production, leading to reduced demand for draft animals. However, transportation affects draft animal use positively and significantly in the short-run. The long-run coefficients of off-farm income variable in columns $4-5$ are negative and statistically significant, suggesting that increased income from off-farm activities appears to reduce draft animal use in sowing and harvesting by $7.16 \%$ and $2.99 \%$, respectively. To some extent, our findings are in line with the findings of Ji et al. [6], who show that off-farm employment in rural China is more likely to reduce production assets such as small-sized machinery. We do not find a significant impact of fertiliser on draft animal use in the long-run, but we find that fertiliser has a positive and statistically significant impact on draft animal use in the short-run. Our estimated results show that fertiliser increases draft animal use at ploughing, sowing and harvesting in the 
short-run by $0.10 \%, 0.14 \%, 0.16 \%$, respectively. Given the chemical fertiliser use has an adverse effect on environmental performance such as microbial biomass decreasing and soil acidification, farmers may choose to use farmyard manure produced by draft animals as a supplementary soil amendment to improve soil quality [33-35].

For the purpose of comparisons, we also estimated the impact of farm machine use on draft animal use, using fixed effects and first difference approaches. The results, which are presented in Table A3 in Appendix A, show that farm machine use has a statistically significant and negative impact on draft animal use, a finding that is consistent with our findings in Table 2. However, fixed effects and first difference approaches, which did not take into account the correlation between the error term and the explanatory, may produce biased estimates. For example, the results estimated by fixed effects and first difference models show that a $1 \%$ increase in farm machine use rate tends to decrease draft animal use by $1.61 \%$ and $0.98 \%$, respectively, which are significantly smaller than the values we observed in Table 2.

\subsection{Impact of Draft Animal Use and Farm Machine Use on Agricultural Productivity}

The results regarding the joint impacts of draft animal use and farm machine use on agricultural productivity are presented in Table 3. In particular, the results estimated from the Cobb-Douglas form are presented in the second column of Table 3, while the results obtained from the translog functional form are presented in the last column of the same table. As discussed earlier, the likelihood ratio (LR) test suggests that the null hypothesis that the Cobb-Douglas form is nested in the translog functional form can be rejected at the $1 \%$ significance level, suggesting the production model should be estimated under a translog form. The further analyses show that the values of AIC and BIC in the translog functional form estimation are smaller than that estimated from the Cobb-Douglas form, confirming the validity of using the results estimated from the translog form for detailed interpretation.

Table 3. Estimation results of the production function.

\begin{tabular}{ccc}
\hline Variable & Cobb-Douglas Form & Translog Form \\
\hline Draft animal use & $0.047(3.707)^{* * *}$ & $0.270(3.386)^{* * *}$ \\
Farm machine use & $-0.041(-2.086)^{* *}$ & $-0.130(-1.129)$ \\
Labour & $-0.044(-0.883)$ & $-0.716(-2.381)^{* *}$ \\
Fertiliser & $0.048(1.918)^{*}$ & $0.735(4.275)^{* * *}$ \\
$t$ & $0.064(37.263)^{* * *}$ & $0.039(4.600)^{* * *}$ \\
Draft animal use $\times$ Draft animal use & & $0.008(0.730)$ \\
Draft animal use $\times$ Farm machine use & & $0.010(0.614)$ \\
Draft animal use $\times$ Labour & & $0.024(1.011)^{*}$ \\
Draft animal use $\times$ Fertiliser & & $0.048(2.184)^{* *}$ \\
Draft animal use $\times t$ & & $-0.008(-6.994)^{* * *}$ \\
Farm machine use $\times$ Farm machine use & & $-0.010(-0.586)$ \\
Farm machine use $\times$ Labour & & $-0.080(-1.367)$ \\
Farm machine use $\times$ Fertiliser & & $-0.078(-2.586)^{* * *}$ \\
Farm machine use $\times t$ & $0.010(6.275)^{* * *}$ \\
Labour $\times$ Labour & & $-0.038(-0.261)$ \\
Labour $\times$ Fertiliser & & $-0.309(-4.599)^{* * *}$ \\
Labour $\times t$ & $0.036(10.034)^{* * *}$ \\
Fertiliser $\times$ Fertiliser & & $0.137(3.147)^{* * *}$ \\
Fertiliser $\times t$ & $-0.001(-0.388)$ \\
$t \times t$ & & $-0.002(-9.948)^{* * *}$ \\
Constant & & $-0.889(-2.322)^{* *}$ \\
$R^{2}$ & $-1.998(-22.473)^{* * *}$ & 0.953 \\
AIC & 0.919 & -955.738 \\
BIC & Chic(15) & -853.099 \\
Observation & -460.661 & 980
\end{tabular}

Note: $t$ statistics in parentheses; ${ }^{* * *} p<0.01,{ }^{* *} p<0.05,{ }^{*} p<0.1$; All variables (except for time trend variable, $t$ ) are expressed as log-transformed forms and measured at per hectare base. 
The results show that the coefficient of draft animal use variable is positive and statistically significant, while the coefficient of the interaction term between draft animal use and the time trend variable (i.e., draft animal use $\times t$ ) is negative and statistically significant. The findings suggest that draft animal use has a positive and significant effect on agricultural productivity, and the effect is declining over time. The coefficient of farm machine use variable is negative and insignificant, while that of the variable representing farm machine use $\times t$ is positive and statistically significant, highlighting that the effect of farm machine use on agricultural productivity is increasing over time.

With respect to other factors that affect agricultural productivity, our results show that the coefficient of labour is negative and statistically significant, suggesting that labour exerts a negative and significant impact on agricultural productivity. The finding of the negative relationship between labour and agricultural productivity may be partially explained by the existence of surplus labour in rural areas. However, the coefficient of interaction term of labour with time is positive and significant, suggesting that labour increases agricultural productivity over time. The coefficient of fertiliser is positive and statistically significant, indicating that the quantity of fertiliser use has a direct positive effect on agricultural productivity, a finding that is in line with previous studies $[5,18,36]$. For example, Wang et al. [5] showed that fertiliser use significantly increases the average yields of wheat, corn, japonica rice, soybean, cotton, and rapeseed in China. The time trend variable is positive and statistically significant, suggesting the existence of technological progress over time.

To ease the understanding, we predicted the output elasticities of draft animal use and farm machine use using Equation (5) and presented the results in Table A4 in Appendix A and Figure 3. The information presented in Figure 3 shows that the output elasticities of draft animal use are diminishing over time. For example, the output elasticity of draft animal use is 0.185 in 1978, and it is only -0.001 in 1998. After 1999, the output elasticities of draft animal use become negative, achieving at -0.129 in 2012. In comparison, the output elasticity of farm machine use is increasing over time. The output elasticity of farm machine use is -0.161 in 1978, and it increases to 0.004 in 1996 . Afterwards, the output elasticity of farm machine use remains positive and increasing, which achieves at 0.170 in 2012. The findings presented in Figure 3 generally confirm the substitutive effect of farm machine use on draft animal use, and highlight the importance of farm machines in increasing agricultural production and productivity over time.

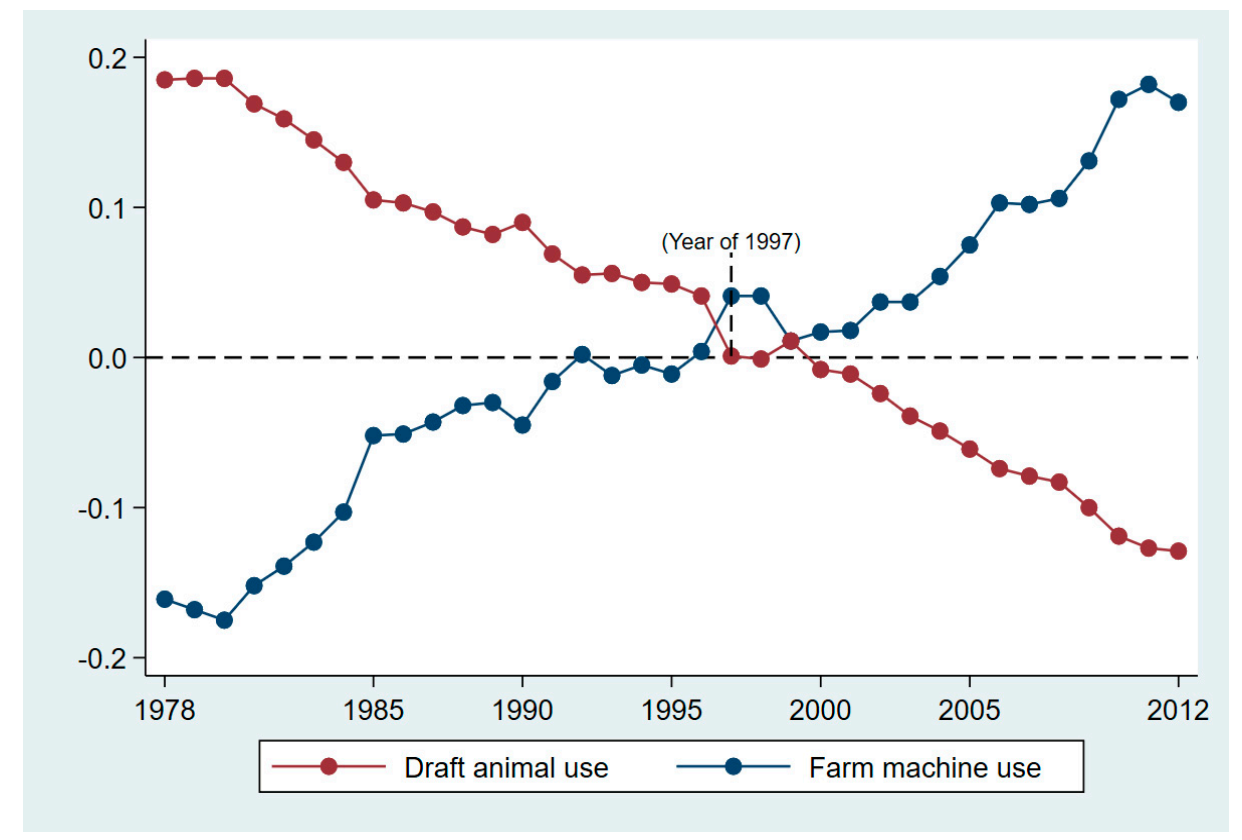

Figure 3. Trends of output elasticities of the draft animal use and farm machine use from 1978 to 2012. 


\section{Conclusions and Policy Implications}

Although agricultural production worldwide has been largely dependent on draft animals for a long time, the emergence and development of farm machines is gradually replacing the role that draft animals have played. However, little is known about the extent to which farm machine use substitutes draft animal use, and how these two agricultural production activities jointly affect agricultural performance. To fill this research gap, this study analysed the long-run and short-run effects of farm machine use on draft animal use using a pooled mean group model, as well as the joint effects of farm machine use and draft animal use on agricultural productivity using a production function model with fixed effects. The data used in the analyses were from 28 provinces of China for the period of 1978-2012, which were collected by the National Bureau of Statistics of China.

The empirical results showed that farm machine use has a long-run significant and negative impact on draft animal use, which decreased draft animal use by $2.82 \%$ in the long-run. However, we found that farm machine use at different production stages including ploughing, sowing and harvesting impacts draft animal use differently. Our estimates revealed that farm machine use in ploughing, sowing and harvesting in the long-run decreases draft animal use by $1.19 \%, 1.26 \%$ and $2.88 \%$, respectively. However, farm machine use did not affect draft animal use in the short-run. In addition, we found that transportation and off-farm income are also important determinants of draft animal use.

The estimates of the panel production function with fixed effects showed that draft animal use and farm machine use affect agricultural productivity from different directions. In particular, our results showed that draft animal use has a positive and statistically significant impact on agricultural productivity, while farm machine use has a negative and insignificant impact on agricultural productivity. The findings with respect to the interaction terms of draft animal use with time and farm machine use with time suggested that the effect of draft animal use on agricultural productivity is decreasing over time, while the effect of farm machine use on agricultural productivity is increasing over time. We found that the output elasticity of draft animal use decreased from 0.185 in 1978 to -0.129 in 2012, while that of farm machine use increased from -0.161 to 0.170 over the same time period. Labour appeared to affect agricultural productivity negatively and significantly, while the effect of labour on agricultural productivity was found to be positive and significant over time. Fertilizer increased agricultural productivity significantly.

Our results have important implications for sustainable agricultural production. The findings of the significant substitution effect of farm machine use on draft animal use and the positive effect of farm machine use on agricultural productivity over time highlight the importance of developing farm machines to support sustainable agricultural production and suggest that the government should intensify its efforts to promote farm machine use in rural areas. Given the fact that not all machines can be adopted in mountainous and hilly regions, the development of farm machines should take into account regional production conditions. Because a subsidy program for farm machine purchasing has been introduced in China, the government may think about providing related training for rural households with respect to the functions of farm machines so as to further enhance the adoption of the mechanical technologies. Although context specific, the results discussed in the present study are relevant to other countries such as India, Ghana, Bangladesh and Kenya that are also making efforts to promote agricultural mechanization with the aim of enhancing sustainable agricultural production. For future studies, it may be significant to examine how farm machine use through different channels such as purchasing machinery services and self-owned machines affects agricultural performance.

A limitation of this study is that due to the nature of the data used we do not have household and farm-level information (e.g., age, gender, household size, credit access, and land type) which may also affect farmers' decisions to use draft animals and farm machines and then affect agricultural productivity. 
Author Contributions: X.Z. conducted most of the original work. The paper was finalised based on W.M. and G.L.'s comments and suggestions.

Funding: This research was funded by National Natural Sciences (grant number: 71473100), the Young Top-notch Talent for Ten Thousand Talent Program (grant number: 2015-48-2-50), and China Rural Research Institute of Tsinghua University (grant number: 201705).

Conflicts of Interest: The authors declare no conflict of interest.

\section{Appendix A}

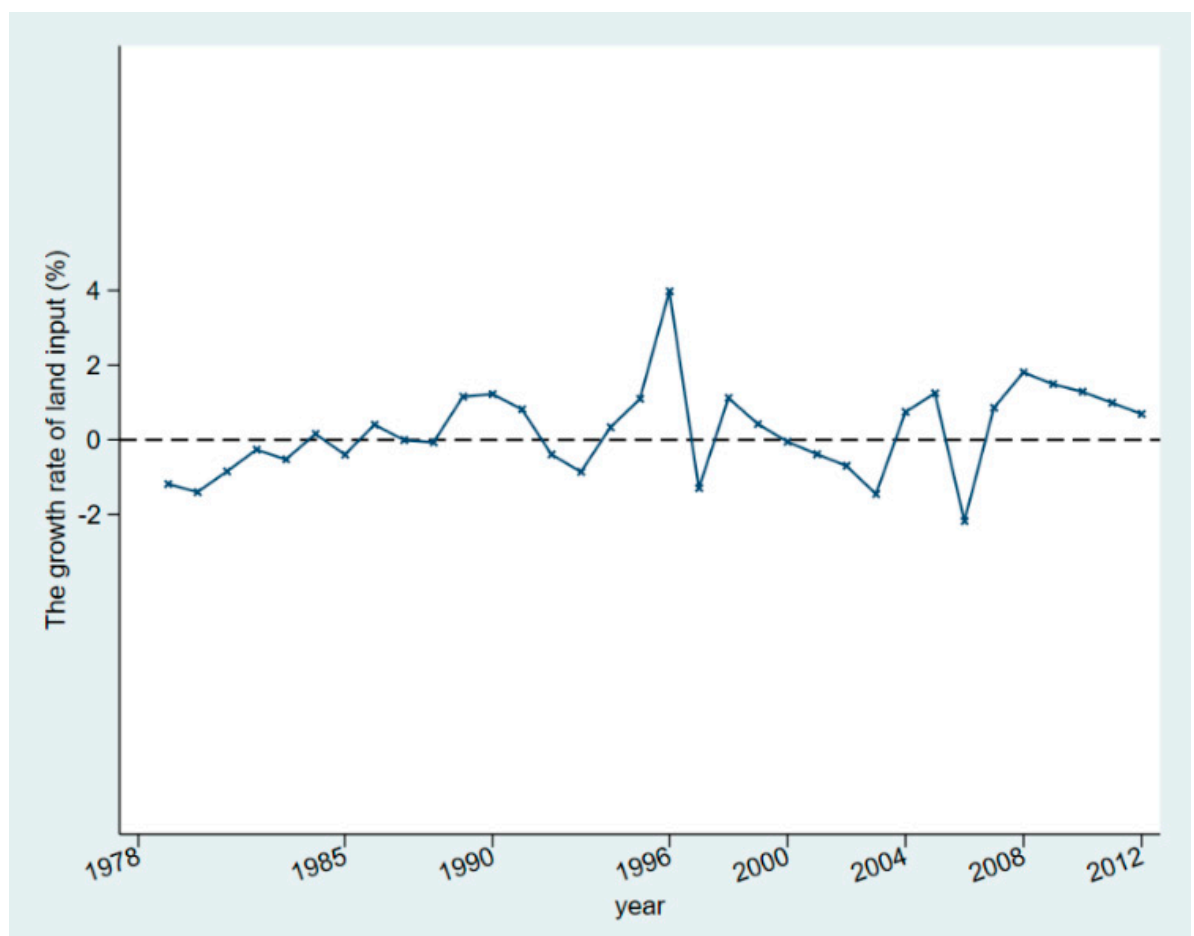

Figure A1. The changes in the growth rate of land input from 1978 to 2012. Note: with the Household contract Responsibility System (HRS) and the arable land red line of 12,000 million hectare, China's rural economy has been based on small farm households, and the amount of arable land can hardly be changed due to the inflexible land rental markets in China.

Table A1. Results of unit root test (IPS) test.

\begin{tabular}{ccccc}
\hline \multirow{2}{*}{ Variable } & \multicolumn{2}{c}{ Without Time Trend } & \multicolumn{2}{c}{ With Time Trend } \\
\cline { 2 - 5 } & Statistic Value & $\boldsymbol{p}$-Value & Statistic Value & $\boldsymbol{p}$-Value \\
\hline Draft animal use & -3.362 & 0.000 & -6.031 & 0.000 \\
Farm machine use & -4.751 & 0.000 & -4.817 & 0.000 \\
Agricultural & -10.991 & 0.000 & -8.109 & 0.000 \\
productivity & -7.799 & 0.000 & -7.101 & 0.000 \\
Labour & -11.884 & 0.000 & -11.986 & 0.000 \\
Fertiliser & -7.529 & 0.000 & -7.895 & 0.000 \\
Transportation & -10.046 & 0.000 & -9.929 & 0.000 \\
Off-farm income & -5.336 & 0.000 & -6.232 & 0.000 \\
Education &
\end{tabular}

Note: The variables are logarithm-transformed and first-order differenced. 
Table A2. Results of cointegration test.

\begin{tabular}{cccc}
\hline Tests & Statistics & Draft Animal Use Model & Production Function Model \\
\hline Westerlund test & Variance ratio & $-2.429(0.008)$ & $-1.462(0.072)$ \\
\hline \multirow{3}{*}{ Pedroni test } & Modified Philips-Perron test & $-2.947(0.002)$ & $-4.672(0.000)$ \\
& Philips-Perron test & $-5.156(0.000)$ & $-1.560(0.059)$ \\
& Augmented Dickey-Fuller test & $-5.690(0.000)$ & $-1.285(0.010)$ \\
\hline
\end{tabular}

Note: $p$-value in parentheses.

Table A3. The impact of farm machine use on draft animal use: FE and FD estimations.

\begin{tabular}{ccc}
\hline Variables & FE Model & FD Model \\
\hline Farm machine use & $-1.608(-1.87)^{*}$ & $-0.977(-3.60)^{* * *}$ \\
Labour & $0.032(0.11)$ & $0.507(3.59)^{* * *}$ \\
Fertiliser & $0.075(0.55)$ & $0.118(3.12)^{* * *}$ \\
Transportation & $-1.143(-3.56)^{* * *}$ & $-0.254(-2.41)^{* *}$ \\
Off-farm income & $-0.617(-3.10)^{* * *}$ & $-0.132(-1.23)$ \\
Education & $0.037(0.40)$ & $-0.080(-1.74)^{*}$ \\
Log Likelihood & -508.652 & 80.542 \\
Observations & 980 & 952
\end{tabular}

Note: $t$ statistics in parentheses; ${ }^{* * *} p<0.01,{ }^{* *} p<0.05,{ }^{*} p<0.1$. FE: Fixed effects; FD: First difference.

Table A4. Trends of production elasticities of the input factors from 1978 to 2012.

\begin{tabular}{cccccc}
\hline \multicolumn{2}{c}{ Period I } & \multicolumn{2}{c}{ Period II } \\
\hline Year & Draft Animal Use & Farm Machine Use & Year & Draft Animal Use & Farm Machine Use \\
\hline 1978 & 0.185 & -0.161 & 1998 & -0.001 & 0.041 \\
1979 & 0.186 & -0.168 & 1999 & 0.011 & 0.011 \\
1980 & 0.186 & -0.175 & 2000 & -0.008 & 0.017 \\
1981 & 0.169 & -0.152 & 2001 & -0.011 & 0.018 \\
1982 & 0.159 & -0.139 & 2002 & -0.024 & 0.037 \\
1983 & 0.145 & -0.123 & 2003 & -0.039 & 0.037 \\
1984 & 0.130 & -0.103 & 2004 & -0.049 & 0.054 \\
1985 & 0.105 & -0.052 & 2005 & -0.061 & 0.075 \\
1986 & 0.103 & -0.051 & 2006 & -0.074 & 0.103 \\
1987 & 0.097 & -0.043 & 2007 & -0.079 & 0.106 \\
1988 & 0.087 & -0.032 & 2008 & -0.083 & 0.131 \\
1989 & 0.082 & -0.030 & 2009 & -0.100 & 0.172 \\
1990 & 0.090 & -0.045 & 2010 & -0.119 & 0.182 \\
1991 & 0.069 & -0.016 & 2011 & -0.127 & 0.170 \\
1992 & 0.055 & 0.002 & 2012 & -0.129 & \\
1993 & 0.056 & -0.012 & & & \\
1994 & 0.050 & -0.005 & & & \\
1995 & 0.049 & -0.011 & & & \\
1996 & 0.041 & 0.004 & & & \\
1997 & 0.001 & 0.041 & & & \\
\hline
\end{tabular}

\section{References}

1. Kienzle, J.; Ashburner, J.E.; Sims, B.G. Mechanization for Rural Development: A Review of Patterns and Progress from around the World. In Integrated Crop Management (FAO) No. 20; Food and Agriculture Organization of the United Nations: Rome, Italy, 2013.

2. Guthiga, P.M.; Karugia, J.T.; Nyikal, R.A. Does use of draft animal power increase economic efficiency of smallholder farms in Kenya? Renew. Agric. Food Syst. 2007, 22, 290-296. [CrossRef]

3. Mrema, G.; Soni, P. A Regional Strategy for Sustainable Agricultural Mechanization: Sustainable Mechanization across Agri-Food Chains in Asia and the Pacific Region; Food and Agriculture Organization of the United Nations: Rome, Italy, 2014. 
4. Ahmed, M.; Goodwin, B. Agricultural Mechanization and Non-Farm Labor Supply of Farm Households: Evidence from Bangladesh. In Proceedings of the the 2016 Agricultural \& Applied Economics Association Annual Meeting, Boston, MA, USA, 31 July-2 August 2015; Volume 1, pp. 1-30.

5. Wang, X.; Yamauchi, F.; Huang, J. Rising wages, mechanization, and the substitution between capital and labor: Evidence from small scale farm system in China. Agric. Econ. 2016, 47, 309-317. [CrossRef]

6. Ji, Y.; Yu, X.; Zhong, F. Machinery investment decision and off-farm employment in rural China. China Econ. Rev. 2012, 23, 71-80. [CrossRef]

7. Sims, B.; Hilmi, M.; Kienzle, J. Agricultural Mechanization: A Key Input for Sub-Saharan African Smallholders. In Integrated Crop Management Integrated Crop Management (FAO) eng v. 23; Food and Agriculture Organization of the United Nations: Rome, Italy, 2016.

8. Pingali, P. Chapter 54 Agricultural Mechanization: Adoption Patterns and Economic Impact. Handb. Agric. Econ. 2007, 3, 2779-2805.

9. Ma, W.; Renwick, A.; Grafton, Q. Farm machinery use, off-farm employment and farm performance in China. Aust. J. Agric. Resour. Econ. 2018, 62, 279-298. [CrossRef]

10. Brotons-Martínez, J.M.; Martin-Gorriz, B.; Torregrosa, A.; Porras, I. Economic evaluation of mechanical harvesting of lemons. Outlook Agric. 2018, 47, 44-50. [CrossRef]

11. Rahman, M.S.; Miah, M.A.M.; Hossain, S. Impact of farm mechanization on labour use for wheat cultivation in northern Bangladesh. J. Anim. Plant Sci. 2011, 21, 589-594.

12. Benin, S. Impact of Ghana's agricultural mechanization services center program. Agric. Econ. 2015, 46, 103-117. [CrossRef]

13. Binswanger, H.P. Agricultural Mechanization: A Comparative Historical Perspective. World Bank Res. Obs. 1986, 1, 27-56. [CrossRef]

14. Jaeger, W.K.; Matlon, P.J. Utilization, Profitability, and the Adoption of Animal Draft Power in West Africa. Am. J. Agric. Econ. 1990, 72, 35. [CrossRef]

15. Qiao, F. Increasing wage, mechanization, and agriculture production in China. China Econ. Rev. 2017, 46, 249-260. [CrossRef]

16. Diao, X.; Cossar, F.; Houssou, N.; Kolavalli, S. Mechanization in Ghana: Emerging demand, and the search for alternative supply models. Food Policy 2014, 48, 168-181. [CrossRef]

17. Kauffman, K.D. Economic factors in the choice of an early form of capital: Draught animals in early twentieth century South Africa. Appl. Econ. Lett. 2000, 7, 69-71. [CrossRef]

18. Fan, S.G. Effects of Technological-Change and Institutional Reform on Production Growth in Chinese Agriculture. Am. J. Agric. Econ. 1991, 73, 266-275. [CrossRef]

19. Yamauchi, F. Rising real wages, mechanization and growing advantage of large farms: Evidence from Indonesia. Food Policy 2016, 58, 62-69. [CrossRef]

20. Takeshima, H.; Nin-Pratt, A.; Diao, X. Mechanization and Agricultural Technology Evolution, Agricultural Intensification in Sub-Saharan Africa: Typology of Agricultural Mechanization in Nigeria. Am. J. Agric. Econ. 2013, 95, 1230-1236. [CrossRef]

21. Zhang, X.; Yang, J.; Wang, S. China has reached the Lewis turning point. China Econ. Rev. 2011, 22, 542-554. [CrossRef]

22. Hayami, Y.; Kawagoe, T. Farm Mechanization, Scale Economies and Polarization. J. Dev. Econ. 1989, 31, 221-239. [CrossRef]

23. Yang, J.; Huang, Z.; Zhang, X.; Reardon, T. The Rapid Rise of Cross-Regional Agricultural Mechanization Services in China. Am. J. Agric. Econ. 2013, 95, 1245-1251. [CrossRef]

24. Pesaran, M.H.; Shin, Y.; Smith, R.P. Pooled Mean Group Estimation of Dynamic Heterogeneous Panels Stable. J. Am. Stat. Assoc. 1999, 94, 621-634. [CrossRef]

25. Iii, E.F.B.; Frank, M.W.; Blackburne, E.F.; Frank, M.W. Estimation of nonstationary heterogeneous panels. Stata J. 2007, 7, 197-208.

26. Kangasniemi, M.; Mas, M.; Robinson, C.; Serrano, L. The economic impact of migration: Productivity analysis for Spain and the UK. J. Product. Anal. 2012, 38, 333-343. [CrossRef]

27. Bachewe, F.; Headey, D. Urban Wage Behaviour and Food Price Inflation in Ethiopia. J. Dev. Stud. 2017, 53, 1207-1222. [CrossRef]

28. Im, K.S.; Pesaran, M.H.; Shin, Y. Testing for unit roots in heterogeneous panels. J. Econ. 2003, 115, 53-74. [CrossRef] 
29. Westerlund, J. Testing for error correction in panel data. Oxf. Bull. Econ. Stat. 2007, 69, 709-748. [CrossRef]

30. Pedroni, P. Panel cointegration: Asymptotic and finite sample properties of pooled time series tests with an application to the PPP hypothesis. Econ. Theory 2004, 20, 597-625. [CrossRef]

31. Abdulai, A.; Tietje, H. Estimating technical efficiency under unobserved heterogeneity with stochastic frontier models: Application to northern German dairy farms. Eur. Rev. Agric. Econ. 2007, 34, $393-416$. [CrossRef]

32. Latruffe, L.; Bravo-Ureta, B.E.; Carpentier, A.; Desjeux, Y.; Moreira, V.H. Subsidies and technical efficiency in agriculture: Evidence from European dairy farms. Am. J. Agric. Econ. 2017, 99, 783-799. [CrossRef]

33. Liu, E.; Yan, C.; Mei, X.; He, W.; Bing, S.H.; Ding, L.; Liu, Q.; Liu, S.; Fan, T. Long-term effect of chemical fertilizer, straw, and manure on soil chemical and biological properties in northwest China. Geoderma 2010, 158, 173-180. [CrossRef]

34. Bokhtiar, S.M.; Sakurai, K. Effects of organic manure and chemical fertilizer on soil fertility and productivity of plant and ratoon crops of sugarcane. Arch. Agron. Soil Sci. 2005, 51, 325-334. [CrossRef]

35. Ma, W.; Abdulai, A.; Goetz, R. Agricultural Cooperatives and Investment in Organic Soil Amendments and Chemical Fertilizer in China. Am. J. Agric. Econ. 2018, 100, 502-520. [CrossRef]

36. Ma, W.; Abdulai, A.; Ma, C. The effects of off-farm work on fertilizer and pesticide expenditures in China. Rev. Dev. Econ. 2018, 22, 573-591. [CrossRef]

(C) 2018 by the authors. Licensee MDPI, Basel, Switzerland. This article is an open access article distributed under the terms and conditions of the Creative Commons Attribution (CC BY) license (http://creativecommons.org/licenses/by/4.0/). 